\title{
Bankruptcy Prediction Model of Banks in Indonesia Based on Capital Adequacy Ratio
}

\author{
Lis Sintha \\ Universitas Kristen Indonesia, Jl. Mayjen Soetoyo No.2, Cawang, Jakarta (13630), Indonesia
}

\begin{abstract}
Objective - The purpose of this study is to examine the influence of capital on bankruptcy banks. The hypothesis of this research is that capital has an effect on the bankruptcy of a bank.

Methodology/Technique - This research examines financial reports between 2005-2014. An econometric model with a logistical regression analysis technique is used. In this study, capital is measured by CAR, taking into account credit risk; CAR by taking into account market risk; Ratio of Obligation to Provide Minimum Capital for Credit Risk and Operational Risk; Ratio of Minimum Capital Adequacy Ratio for Credit Risk, Operational Risk and Market Risk; Capital Adequacy Requirements (CAR).

Findings - The results show that the capital adequacy ratio for market ratio and capital adequacy ratio for credit ratio and operational ratio support the research hypothesis and can form a logit model. The test results of CAR by taking into account credit risk, Minimum Capital Requirement Ratio for Credit Risk, Operational Risk and Market Risk and Minimum Capital Provision Obligations do not support the research hypothesis.
\end{abstract}

Novelty - This paper contribute to bank bankruptcy prediction models based on time dimension and bank groups using financial ratios which are expected can influence bank in bankrupt condition.

Type of Paper: Empirical.

JEL Classification: G32, G33, G39.

Keywords: Banking crisis, Cost of bankruptcy, Adequacy Ratio, Financial ratios, Prediction models

\section{Introduction}

Banking refers to the institutions that collect and channel public funds; they have an important role in supporting national development. Given their integral role in society, it is important that banks operate efficiently and effectively. One way to review the operation of banks is by assessing their financial statements.

\footnotetext{
* Paper Info: Received: December 17, 2018

Accepted: March 19, 2019

* Corresponding author:

E-mail: lis.shinta@uki.ac.id

Affiliation: Universitas Kristen Indonesia, J1. Mayjen Soetoyo no.2, Cawang, Jakarta (13630), Indonesia
} 
Since 2011, the RGEC method (Risk Profile, GCG, Earning, Capital) has been used to measure the health of banks. The bank's health assessment model is loaded with risk management. Risk Profile is an assessment of inherent risk and the quality of the application of Risk Management in a bank's operational activities including 8 (eight) types of risk, namely: good corporate governance, earnings, and capital.

The bank's capital in this study is referred to as the Capital Adequacy Ratio (CAR). There are many factors that can affect profitability, one of which is the Capital Adequacy Ratio (CAR). The Capital Adequacy Ratio (CAR) is a ratio that demonstrates the level of capital adequacy, which is the amount of capital needed to cover the risk of losses. The higher the CAR, the higher the ROE will be. The CAR shows the level of bank compliance with regulations that serve and protect the public interest, (Supriyatna, et. al., 2007). In addition, the CAR also indicates the bank's sensitivity to public interest. The higher the CAR, the more sensitive the bank is to the public interest. However, if the CAR low, this indicates that the bank's sensitivity to the public is low.

Research to examine the effect of Capital Adequacy Ratio (CAR) on bank conditions has been carried out by many researchers. However, a lot of those studies have resulted in inconsistent findings. Suharman (2007) states that CAR has a significant and negative effect on the health of a bank whilst Santoso (1996) and Sinkey (1975) state that CAR has a significant and positive effect on the health of a bank. On the other hand, Haryati's (2006) provided insignificant results on this topic.

In this study, capital is measured as CAR by calculating credit risk; CAR by calculating market risk; Obligation Ratio Providing Minimum Capital for Credit Risk and Operational Risk (Capital Adequacy Ratio For Credit Risk and Operational risk); Minimum Capital Requirement Ratio for Credit Risk, Operational Risk and Market Risk (Capital Adequacy Ratio for Credit Risk, Operational Risk); Minimum Capital Adequacy Ratio (CAR).

Based on the discussion above, the following questions are posed:

1. How does the Capital Adequacy Ratio prediction model effect the health of a bank.

2. How accurate is the Capital Adequacy Ratio in predicting the bankruptcy of a bank?

\section{Literature Review}

\subsection{Bank Health}

Bank health is the ability of banks to carry out banking operations normally and to fulfill their obligations in ways that comply with applicable banking regulations (Santoso, 2006:51). The soundness of a bank refers to the financial condition and management of the bank as measured by the calculation of ratios. The soundness of the bank is in the interest of all parties involved including the owners and managers of the bank, the community using the services of the bank, and the Indonesian bank as the supervisor of banks in Indonesia (Sunarti, 2011:144).

Almilia and Herdiningtyas (2005) have conducted empirical research on the level of business failure and bankruptcy among banks using the CAMELS model. The results of that study show that Capital Adequacy Ratio (CAR) is significantly and negatively related to problematic conditions. Santoso and Triandaru (2006) state that bank health refers to the ability of a bank to carry out its g operations normally and to fulfill its obligations in accordance with applicable regulations. If a bank's CAR increases, their risk will decrease and their profits will generally increase (Yuliani, 2007).

In calculating capital, banks must refer to the regulations made by the Bank of Indonesia which govern Minimum Capital Requirements for commercial banks. In addition, in assessing the adequacy of capital, banks must also link capital adequacy with the bank's risk profile. The higher the risk, the more capital must be provided to anticipate the risk. 


\subsection{Capital}

In regulating the capital of banks in Indonesia, the Bank of Indonesia has adopted the capital provisions issued by the International Settlement Bank (BIS) which require that the amount of bank capital be at least $8 \%$ of the total assets at risk, which are known as WAAR (Weighted Assets According to Risk).

In terms of assets, high capital adequacy will provide an opportunity to diversify assets and can enable banks to expand their operations to improve their profitability and performance, (Rose, 2002). Adequate bank capital covers the level of asset risk so that the bank's performance will improve. This is due to an increase in the level of trust of customers to deposit their funds, despite high interest rates.

The results of research in Indonesia conducted by Sudiyatno and Soroso, 2010 show that capital adequacy ratio (CAR) has a significant and positive relationship with banking performance. Whereas research by Sudiyatno and Setyowati (2012), Rusdini (2012) and Amalia (2010) show that CAR does not affect the performance of banks.

An assessment of capital factors includes an assessment of the level of capital adequacy and capital management. The indicators used for capital include the Capital Adequacy Ratio (CAR) which is an important factor for the business development of banks. The CAR highlights the extent to which a decrease in bank assets can be managed by a bank's available equity; the higher the CAR, the better the condition of a bank is (Tarmidzi Achmad, 2003).

The Minimum Capital Liability is calculated according to risk profile (SE No. 14/37 / DPNP, 27 December 2012). Banks are required to provide minimum capital in accordance with risk profiles, both individually and on a consolidated basis. Meeting the needs of the Bank's Minimum Capital Ratio is determined by the BIS (Bank for International Settlement) and must be at least $8 \%$.

The CAR value is obtained by using the following formula:

(Capital: WAAR) x 100\%.

Capital consists of Core Capital (Tier 1) and Complementary Capital (Tier 2), where the amount of Supplementary Capital is calculated to be a maximum of $100 \%$ of the amount of Core Capital. If credit risk, market risk and operational risk are included, these risks will add to the calculation of WAAR.

CAR is calculated by taking into account Credit Risk to measure the capital adequacy of the bank in supporting assets that contain or produce risks, for example, loans. The greater the percentage of CAR, the better equipped a bank will be when dealing with risky assets. Based on the regulations implemented by the Bank of Indonesia, healthy banks must have a CAR of at least $8 \%$.

The health of a bank taking into account the capital rating factor measured by credit risk, market risk and operational risk is shown in the figure below. 


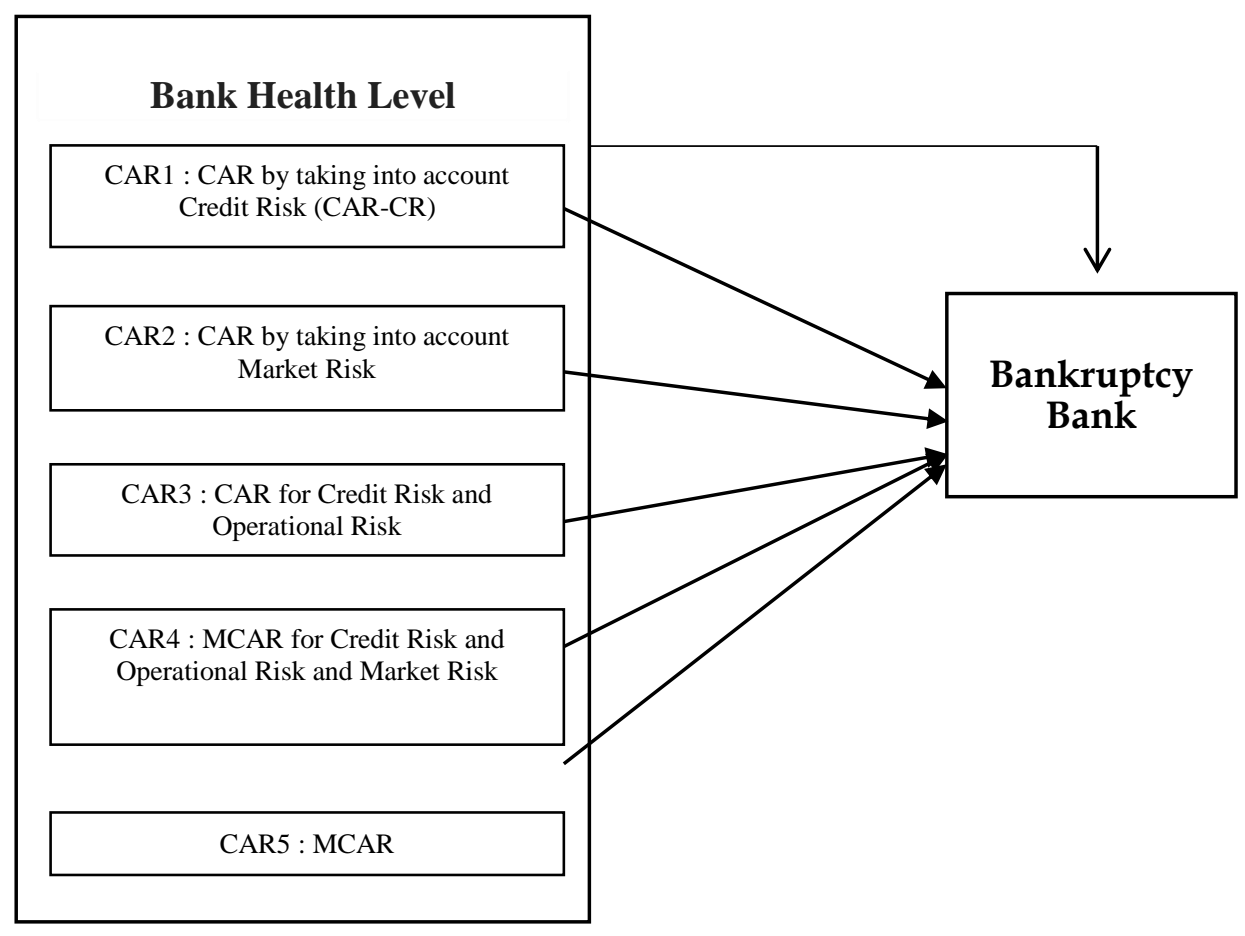

Figure 1. Relationship of Capital Variables

\section{Research Methodology}

The population in this study include banks located in Indonesia and listed in the Indonesian Banking Directory Book. The sample was selected using purposive sampling. Based on the above criteria, 74 banks were selected from 2005 - 2014 consisting of 13 troubled / bankrupt banks and 61 non-bankrupt banks. This study uses a Logit model to predict bankruptcy with a relatively small sample size (Stone \& Rasp, 1991).

\subsection{Variable Operationalization}

The Capital Parameters / Indicators matrix in this study are:

CAR by calculating credit risk

CAR by calculating market risk

Ratio of Capital Adequacy Ratio to Credit Risk and Operational Risk (Capital Adequacy Ratio for Credit Risk and Operational Risk)

Minimum Capital Requirement Ratio for Credit Risk, Operational Risk and Market Risk (Capital

Adequacy Ratio for Credit Risk, Operational Risk)

Minimum Capital Requirement (CAR)

Logit analysis is used to develop a model that is expected to predict the probability that a bank will enter bankruptcy. The bankruptcy status of the bank is dichotomous, where $\mathrm{Y}=1$, meaning the bank is bankrupt, and $\mathrm{Y}=0$, which means that the bank is healthy (not bankrupt) . 
Table 1. Operationalization of Research Variables

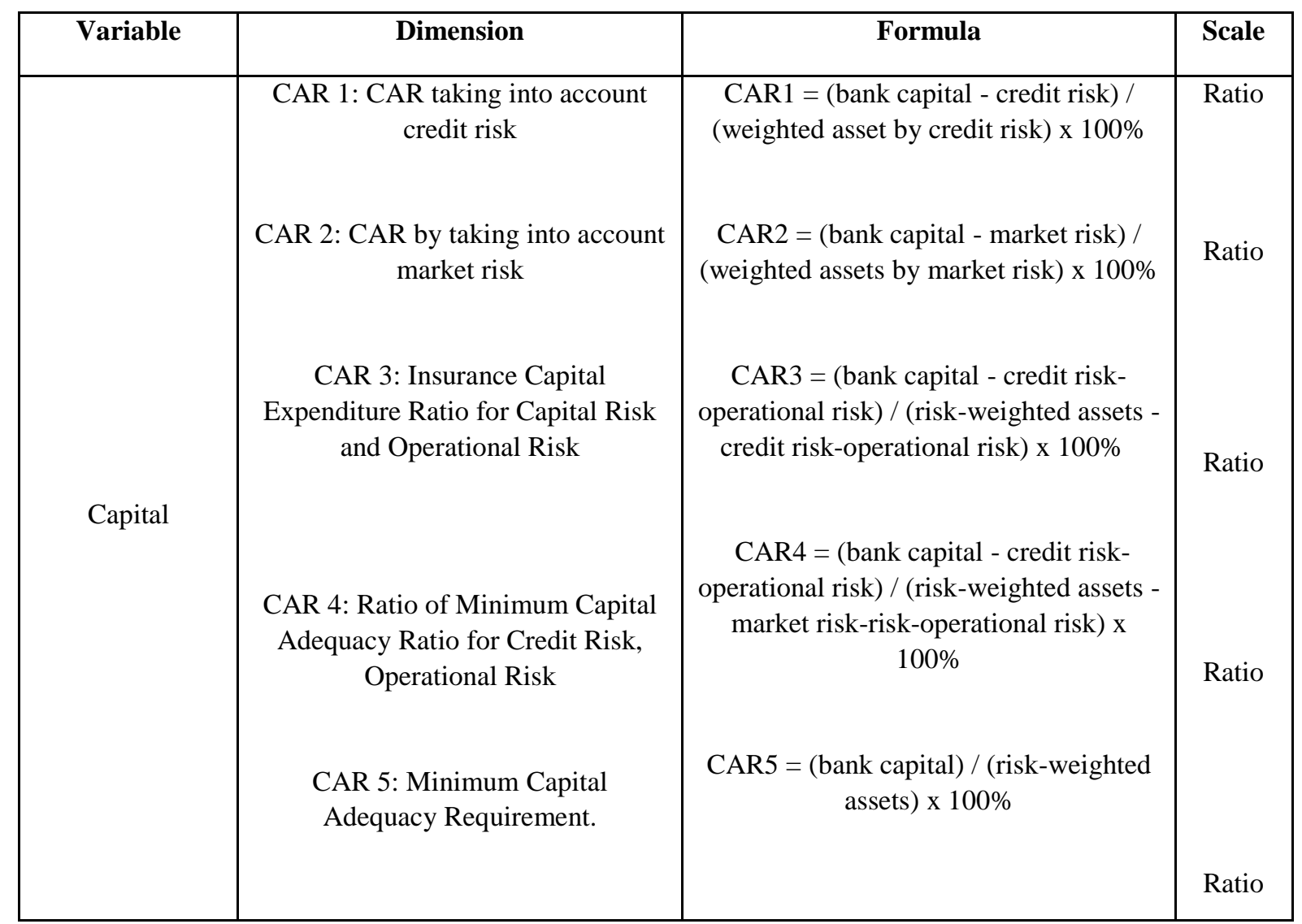

\section{Results}

The description of the capital variables in Table 2 show that there are differences in the average rating of the Capital Adequacy Ratio when taking into account Credit Risk (CAR1), Capital Adequacy Ratio Market Risk (CAR2), Capital Adequacy Ratio for Credit Risk and Operational Risk (CAR3 ), Capital Adequacy Ratio of Credit Risk, Market Risk and Operational Risk (CAR4) and Capital Adequacy Ratio (CAR5), which are smaller in healthy banks as compared to at risk banks.

With respect to Capital Adequacy Ratio taking into account Credit Risk (CAR1) and Capital Adequacy Ratio Market Risk (CAR2), the difference is reinforced by the results of the t-test that yield a probability significance below 0.05. It can therefore be concluded that the average CAR1 and CAR2 in banks that have experienced bankruptcy and those that haven't differ significantly.

With respect to the Capital Adequacy Ratio for Credit Risk and Operational Risk (CAR3), Capital Adequacy Ratio of Credit Risk, Market Risk and Operational Risk (CAR4) and Capital Adequacy Ratio (CAR5 ), the results of the t-test show a probability significance above 0.05 . It can therefore be concluded that the average CAR3, CAR4 and CAR5 in banks that have experienced bankruptcy and those that haven't is different but not significant. 
Table 2. Description of Capital

\begin{tabular}{|c|c|c|c|c|c|c|c|}
\hline \multirow{2}{*}{ Variables } & \multicolumn{3}{|c|}{ Panel A } & \multicolumn{3}{c|}{ Panel B } & P-value \\
\cline { 2 - 7 } & \multicolumn{2}{|c|}{ Non Bankruptcy $=1.850$} & \multicolumn{3}{c|}{ Bankruptcy $=70$} & T test \\
\cline { 2 - 7 } & Mean & Max & Min & Mean & Max & Min & \\
\hline CAR1 & 11,720 & 166.03 & -39.62 & 45.351 & 372.59 & 0.16 & 0.000 \\
\hline CAR2 & 20464 & 144.63 & -22.29 & 56.912 & 372.59 & 0 & 0.000 \\
\hline CAR3 & 20365 & 166.03 & -39.62 & 147.791 & 6231 & 10.58 & 0.154 \\
\hline CAR4 & 19874 & 144.63 & -22.29 & 145.216 & 6227 & 0 & 0.161 \\
\hline CAR5 & 13.830 & 94.61 & 0 & 21.636 & 349.41 & 8 & 0.149 \\
\hline
\end{tabular}

Source: BI data processed, 2017

\section{Effect of Capital on Bank Bankruptcy Predictions}

$\operatorname{Logit}(\mathrm{y})=-5.953+0.093\left(\mathrm{CAR}_{1}\right)-0.062\left(\mathrm{CAR}_{2}\right)-0.043\left(\mathrm{CARCROR}_{3}\right)+0.07\left(\mathrm{CAR}_{4}\right)+0.115$ $\left(\mathrm{CAR}_{5}\right)$

Table 3. Hypothesis Testing Results Capital Models

\begin{tabular}{|c|c|c|c|c|c|}
\hline Variable & Prediction & Koefisien & Wald & Exp (B) & Result \\
\hline Constants & & -5.953 & 289.33 & 0.003 & Not Supported \\
\hline CAR1 & Negative (-) & 0.093 & 15.87 & 1.098 & Supported \\
\hline CAR2 & Negative (-) & -0.062 & 5.64 & 0.940 & Supported \\
\hline CAR3 & Negative (-) & -0.043 & 1.74 & 0.958 & Not Supported \\
\hline CAR4 & Negative (-) & 0.070 & 4.22 & 1.072 & Not Supported \\
\hline CAR5 & Negative (-) & 0.115 & 16.68 & 1.122 & \\
\hline Negelkerke R2 & & $29.70 \%$ & & & \\
\hline
\end{tabular}

Source: Processed Data 2017*** Supported statistically on alpha 1\%, ** at alpha 5\%, and * at alpha $10 \%$.

The table above summarizes the results of tests of capital influence in terms of capital adequacy ratio credit ratio

(CAR1), capital adequacy ratio market ratio (CAR2). capital adequacy ratio of credit ratio and operational ratio (CAR3), capital adequacy ratio of credit ratio, market ratio and operational ratio (CAR4) and capital adequacy ratio (CAR5) to bank insolvency.

The initial hypothesis predicted that the capital adequacy ratio of credit ratio (CAR1) negatively affects the health of a bank. Based on the results of the output as shown in the table above, the coefficient of capital adequacy ratio credit ratio (CAR1) is 0.093 , which means that the value of the odds ratio or bankruptcy probability of exp will increase (0.093). The logit model does not support the hypothesis that the capital adequacy ratio of credit ratio (CAR1) does not negatively affect bank insolvency, so the capital adequacy ratio credit ratio (CAR1) is not able to form the logit model.

The value of the capital adequacy ratio (CAR2) is -0.062 , meaning that the results of the logit model research support the hypothesis that capital adequacy ratio market ratio (CAR2) has a negative affects on the insolvency of a bank with a 5\% significance level. The higher the capital adequacy market ratio (CAR2), the 
more likely a bank will become insolvent and vice versa, hence, the capital adequacy market ratio (CAR2) variable can be used in the logit regression model equation.

The coefficient of the capital adequacy ratio of credit ratio and operational ratio (CAR3) is - 0.043 meaning that an increase in CAR3 will cause a decrease in the value of bank odds ratio or the probability of insolvency by exp (-0.043) or equal to 0.958 . The results of the logit model research supports the hypothesis that the capital adequacy ratio of credit ratio and operational ratio (CAR3) have a negative effect on the insolvency of a bank at a 5\% significance level. The higher the capital adequacy ratio of credit ratio and operational ratio (CAR3), the more likely a bank will become insolvent and vice versa. Hence, capital adequacy ratio of credit ratio and operational ratio (CAR3) can form part of the logit regression model equation.

The value of the coefficient of capital adequacy ratio of credit ratio, market ratio and operational ratio (CAR4) is 0.070 which means that the logit model does not support the hypothesis that the capital adequacy ratio of credit ratio, market ratio and operational ratio (CAR4) have a negative effect on bank insolvency. Hence, that variable cannot form part of the logit regression model.

The value of the capital adequacy ratio (CAR5) coefficient is 0.115 , which means that the results of the logit model do not support the hypothesis that capital adequacy ratio (CAR5) has a negative effect on bank insolvency. Hence, capital adequacy ratio (CAR5) cannot form part of the logit regression model equation.

It can be concluded that of the five indicators of capital variables, only capital adequacy ratio market ratio (CAR2) and capital adequacy ratio credit ratio and operational ratio (CAR3) support the research hypothesis and can form part of the variable logit regression model. Meanwhile CAR1, CAR3 and CAR5 do not support the research hypothesis.

The results of this study are consistent with the findings of Haryati (2006) who states that CAR5 has no significant effect on the probability of bankruptcy. The absence of a significant influence between CAR5 on the probability of bankruptcy is due to the fact that the whole bank already has a high CAR. This is indicated by the descriptive statistic in Table 3 whereby the minimum value of CAR5 for a bankrupt bank is $8 \%$ and for a non-bankrupt bank is $0 \%$.

CAR is one indicator of bank capital health. Capital Assessment is an assessment of the adequacy of bank capital to cover current risk exposure and anticipate future risk exposure. CAR1 is a bank performance ratio that is used to measure the capital adequacy of a bank in supporting its assets that contain or generate risks, such as loans. A higher CAR1 indicates greater endurance in the face of the depreciation of bank property arising from the presence of troubled assets. Based on the provisions of the Bank of Indonesia, banks declared as healthy banks must have a CAR of at least $8 \%$.

The results of this study do not support the research of Almilia and Herdiningtyas (2005) which states that CAR has a significant and negative effect on the prediction of troubled condition in the banking sector. The results are also inconsistent with research by Santoso (1996) which states that the bigger the ratio, the less probability of insolvency. Capital Adequacy Ratio (CAR) is important for banks in the framework of business development and their ability to accommodate the risk of losses caused by bank operations. The higher the coefficient, the higher the risk of bankruptcy. The results of this study support research conducted by Sudiyatno and Setyowati (2012), Rusdini (2012) and Amalia (2010) which state that CAR does not affect bank performance and rejects the findings of Rose (2002) which states that a high level of capital adequacy will provide opportunities for diversification of asset to enable the bank to expand and increase its financial performance.

\section{Discussion}

The model test results support the hypothesis that capital has an effect on bank insolvency. Based on the results of the hypothesis test, the findings of the model are as follows: 
Logit $\mathrm{P}(\mathrm{y}=1 \mid \mathrm{x} 1)=-5.953-0.062(\mathrm{CAR} 2)-0.043(\mathrm{CAR} 3)$

The model diagram is shown in the picture below:

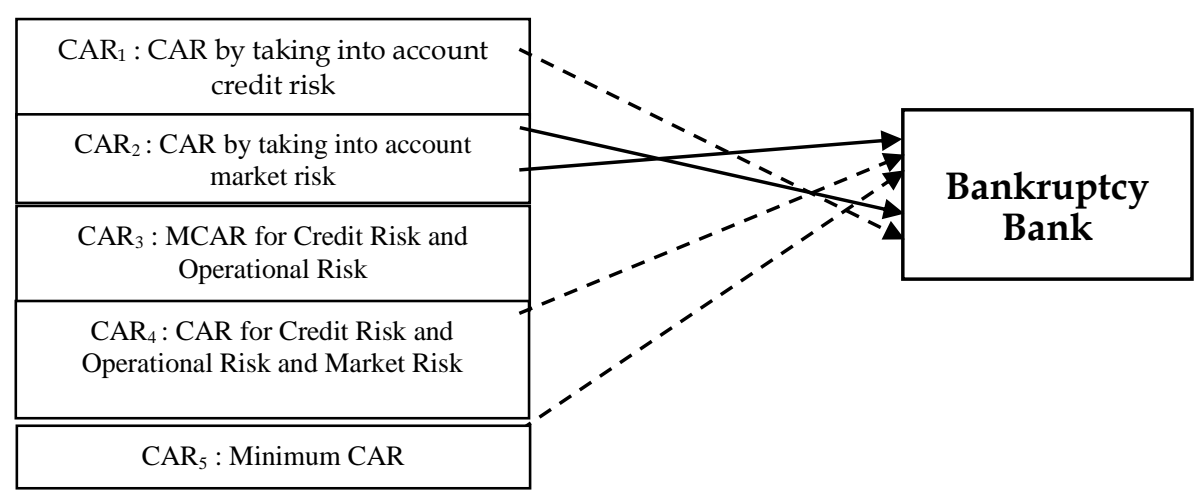

Figure 2. Novelty Research Model Capital

The above model states that bank insolvency in Indonesia is determined by capital that is capitalized by the capital adequacy market ratio (CAR2) and capital adequacy credit ratio and operational ratio (CAR3). Capital valuation is an assessment of the adequacy of bank capital to cover current risk exposure and anticipate future risk. The greater the capital adequacy of a bank, the more likely a bank can handle a depreciation of its property values.

Overall, the results of this study support the findings of Pantalone and Platt (1987) and Ou and Penman (1989) which state that bank failures can be accurately predicted despite the publication of information as a basis for limited predictions, and financial ratios can be used to predict future events by linking financial ratios with economic phenomena.

\section{Conclusion}

It can be concluded that from the five variable capital indicators, only the capital adequacy ratio market ratio (CAR2) and the capital adequacy ratio credit ratio and operational ratio (CAR3) support the research hypothesis and can form a variable capital logit model. Meanwhile, the results of the testing of CAR1, CAR4 and CAR5 do not support the research hypothesis.

This study is limited by the relatively low adjusted $\mathrm{R} 2$ value of $29.70 \%$. Therefore, future research may wish to add other variables that influence the assessment of bank soundness such as risk profile, good corporate governance and earnings. Future research should also examine a longer study period, to ensure that the results can be generalized.

\section{References}

Almilia, Luciana Spica, and Winny Herdiningtyas, (2005). Analysis of the Camel Ratio to Predictions of Troubled Conditions in Banking Institutions Period 2000-2002. Journal of Accounting and Finance. 7 (2), STIE Perbanas, Surabaya, 12.

Altman, E., R. Haldeman, and P. Narayanan, (1977). ZETA Analysis: A New Model to Identify Bankruptcy Risk of Corporations, Journal of Banking and Finance.

Arturo Estrella, Sangkyun Park, and Stavros Peristiani, (2002). Capital Ratios and Credit Ratings as Predictors of Bank Failures.

Arturo Estrella, Sangkyun Park, and Stavros Peristiani,(2000). Capital Ratios as Predictors of Bank Failure Capital, FRBNY Economic Policy Review. 
Aryati and Manao, Financial Ratios as Predictors of Problem Banks in Indonesia, (2002). JRAI Vol 5 No. 2. Asquith P. R. Gertner dan D. Scharfstein. (1994). Anatomy of Financial Distress: An Examination of Junk-Bond Brinkman, E.J dan P.M. Horvitz: Risk based capital standards and the credit crunch. (Journal of Money, Credit and Banking, vol. 27(3)

De Bondt, G. J., and Prast, H. M, (2000). "Bank Capital Ratios in the1990s: Cross-Country Evidence". Banca Nazionale del Lavoro., Quarterly Riview.” the Quarterly Review, Vol. 212, Pp. 72-97.

Gardener, E.P.N., "Capital Adequacy and Banking Supervision: Towards a Practical System”., Journal of Research, summer,

Godlewski, C.J. (1982). Bank Capital and Credit Risk Taking in Emerging Market Economies, - Journal of Banking Regulation, 2005 - palgrave-journals.com

Hadad, M., W., Santoso, and I., Rulina, (2003). Bankruptcy Indicators in Indonesia: An Early Warning Tools on Financial System Stability, Bank Research Paper

Hamonangan, Reynaldo and Hasan Sakti (2009). Effect of Capital Adequacy Ratio, Debt to Equity Ratio, NonPerforming Loans, Operating Ratio and Loan to Deposit Ratio on Return on Equity in banking companies listed on the Indonesia Stock Exchange

Martin, D., (1977). Early Warning of Bank Failure: A Logit Regression Approach," Journal of Banking and Finance, 1, 249-276.

Stuhr, D. P. and R. Van Wicklin (1974), "Rating the inancial Condition of Banks: A Statistical Approach to Aid Bank Supervision," Monthly Review , Federal Reserve Bank of New York, September, pp. 233-238

Suharman, H. (2007). "Financial Risk Analysis to Predict the Level of Bank Business Failure." IMET ASET Journal of the Center for Research and Community Service School of Economics, Vol. 9, No. February 1.

Basel Committee on Banking Supervision (2004), International Convergence of Capital Measurement and Capital Standards. A Revised Framework, Basel: Bank for International Settlements.

Gujarati. Damodar N., and Awn C. Poter (2010). Basics of Econometrics in Jakarta: Salemba Empat Issuers. Quarterly Journal of Economics 109: 625-658 